\title{
МОНГОЛ АЛТАЙН НУРУУНЫ ОЙГ ХАДГАЛАН ХАМГААЛАХ АРГА ЗАМ
}

\author{
П. Баттулга \\ ШУА-ийн Геоэкологийн хүрээлэн \\ Цахим иуудан: Ptulga_ncn@yahoo.com
}

\section{Хураангуй}

Дэлхий дахины ач холбогдолтой онцлог экосистем бүхий нутаг дэвсгэрийн байгалийн унаган төрхийг хэвээр хадгалах, биологийн төрөл зүйлийг хамгаалах, тоо толгойг нэмэгдүүлэх зорилготой Экобүс нутагт Монгол Алтайн экосистем багтсан нь тус бүс нутгийн байгаль, ан амьтныг хамгаалах, бүс нутгийн тогтвортой хөгжлийг хангах боломжийг орон нутгийн нөөц, баялаг, ард иргэдийн оролцоонд түшиглэн хөгжүүлэхэд чухал ач холбогдолтой юм. Монгол Алтайн нурууны ой нь Монгол орны ой-ургамалжилтын мужлалаар Төв Азийн ой ургамалжилтын мужийн Монгол Алтайн хошуунд хамаарна [1]. Монгол Алтайн уулсын систем нь Монгол орны баруун өмнөд хэсэгт баруунаас зүүн тийш 800 гаруй км урт сунаж тогтсон байдаг. Монгол Алтайн нурууны ой нийтдээ 112.0 мян. га талбайтай ба энэ нь Монгол орны ойгоор бүрхэгдсэн талбайн зөвхөн 1 орчим хувийг эзэлнэ. Монгол Алтайн нуруунд зөвхөн тайгажуу болон цармын ой тархдаг ба тайгажуу ой нь д.т.д 2100-2300 м өндөрт, харин цармын ой нь д.т.д 2300-2700 м өндөрт н ургана. Тус бүс нутагт төгөл тархалттай ургах ойн бүлгэмдлийн шинж чанар, байгалийн сэргэн ургалтын төлөв байдлыг тодорхойлон, эдгээрт үндэслэн ойг хамгаалах загварчлалыг боловсруулж, ургах орчин нөхцөл муу, ойн өсөлт, бүтээмж бага зэрэг өвөрмөц онцлогтой тус ойг хадгалан хамгаалах асуудлыг энд дэвшүүлж байна.

Түлхүур үг: сэргэн ургалт, иухуйи, загвар, аж ахуй, хамгаалал

\section{УДИРТГАЛ}

Ойн нөөц баялгийн төлөв байдал, түүний хувьсал өөрчлөлтийг таниж мэдэх улмаар тэдгээрийн тоон болон чанарын үнэлгээг зөв тогтоох нь байгалийн нөөц баялгийг зохистой ашиглах, хамгаалах нөхөн сэргээх бодлогыг төлөвлөх, практик арга хэмжээг авч хэрэгжүүлэхэд нэн чухал ач холбогдолтой юм.

Манай гаригийн биологийн олон янз байдлыг хамгаалах хамгийн үр дүнтэй арга зам нь тэдгээрийн амьдрах нутгийг иж бүрэн хамгаалах явдал юм. Биологийн бүлгэмдлийг хамгаалан үлдээх 4 гол арга зам байдаг. Үүнд:

1. Газар нутгийг тусгай хамгаалалтанд авах замаар хамгаалах;
2. Тусгай хамгаалалтанд авсан газар нутгийн үр дүнтэй менежментийг бий болгох;

3. Зөвхөн тусгай хамгаалалттай газар нутгаар хязгаарлалгүй, тэдгээрийн хилийн гадна ч зүйлийг хамгаалах үйл ажиллагааг үргэлжлүүлэн хэрэгжүүлэх;

4. Сөрөг нөлөөлөлд өртсөн амьдрах орчны биологийн бүлгэмдлийг нөхөн сэргээх зэрэг болно[2].

Биологийн олон янз байдлыг хамгаалах хамгийн найдвартай хэрэгсэл бол бүх төрлийн амьдрах орчинг аль болох байгалийн анхдагч төрхөөр нь хадгалан үлдээх явдал юм [3]. 
Ой мод нь нөөц баялаг, экологийн орчинг бүрдүүлэх, нийгэм-аж ахуйн хэрэгцээт нөхцлийг бий болгоход асар их ач холбогдолтой өндөр үүрэг гүйцэтгэдэг билээ. Энэхүү үүрэг, ач холбогдлыг хадгалан улмаар сайжруулахад тухайн ойд тохирсон ойн аж ахуйн менежмент чухал юм.

Монгол оронд ойн аж ахуйн хөгжилт төдийлөн эрчимтэй бус байгаа өнөөгийн зах зээлийн нөхцөлд ойн менежментийг ой ургамалжилтын муж, хошуудын онцлогийг харгалзан явуулбал зохино. Манай орны өнөөгийн нөхцөлд ойн аж ахуйн менежмент нь ой модыг огтолж ашиглахаас илүүтэй, харин түүний хамгаалан-тогтонгишуулах Үүргийг хэвээр байлгах, ихэсгэхэд голлон чиглэгдэх ёстой [4].

Монгол Алтайн нурууны шинэсэн ойн төлөв байдал, өсөлтийн онцлог, ургах орчин нөхцөл, байгалийн сэргэн ургалтын үйл явц, онцлог зэрэг нь ойг хамгаалах арга замыг төлөвлөх, хөтлөн явуулах, авч хэрэгжүүлэх боломж, чиглэлийг тогтоох үндэслэл болох юм.

Тус бүс нутгийн ойн өсөлт, бүтээмж, байгалийн сэргэн ургалт, ойн хөрс ба ургамалжилтын нарийвчилсан судалгаa байхгүйгээс гадна Монгол орны ойн тархалтын баруун өмнөд хилийн ой болохын хувьд түүний онцлогийг судлан тогтоох нь төгөл тархалттай тус бүс нутгийн ойг хэвээр хадгалан хамгаалах, нөхөн сэргээх, нөөцийг нэмэгдүүлэх шинжлэх ухааны үндэслэлийг бий болгох нь зайлшгүй шийдвэрлэх асуудлын нэг болж байна. Иймээс тус бүс нутгийн ойн шинж чанарыг зөв тогтоосноор ойн нөөцийн бүртгэл тооллогын ажлын чанарын түвшинг дээшлүүлэх, ойн нөөцийн менежментийг боловсронгуй болгох, ойн бүтэц, бүрэлдэхүүн, шинж чанарыг сайжруулах зэрэг ойн аж ахуйн арга хэмжээний төлөвлөлтийг авч явуулахад зохих хувь нэмэр болох юм.

Монгол Алтайд МОХБИБЭ-ийн ойн судлаачид 1973 онд Говь-Алтайн аймгийн Тайшир, Ховд аймгийн Дарви, улмаар Баян-Өлгий аймгийн нутагт хамаарах Ховд голын дагуух төгөл зураа ойд судалгаа хийж, ойн өргөгдөл бүслүүрийн зүй тогтол, ойн зонхилох хэвшинжүүд, тэдгээрийн таксацийн бүтэц, бүрэлдэхүүнийг тогтоожээ [5].

Алтай Соёны экобүс нутгийн биологийг төрөл зүйлийг хамгаaлах, тогтвортой ашиглах төслийн хүрээнд 2002 онд явуут судалгааг хийж, ойн тархалт, ашиглалтын байдлыг тоймчлон тогтоосон байна [6].

Монгол Алтайн нурууны ургамалжилтын тархац, бүс, бүслүүрийн болон зонхилох хэвшинжүүдийн зүй тогтлыг илрүүлж ангилал зохиох, тухайн нурууны системийн хэмжээнд ботаникгазарзүйн мужлалыг шинэчлэн хийж, Евразийн ботаник газарзүйн мужлалд түүний эзлэх байр суурийг тодорхойлох, цаашид ургамлын бүрхэвчийг ашиглах, хамгаалах асуудлуудыг боловсруулжээ [7].

\section{СУДАЛГААНЫ АРГАЗУЙ, ЦУГЛУУЛСАН МАТЕРИАЛ}

Байгалийн шинэсэн ойд дээж талбай байгуулах, загвар мод авах болон материал боловсруулалтын ажлыг В. С. Моисеев (1971), А. Г. Мошкалев ба бусад (1988), В. С. Моисеев ба бусад (1987), Н. П. Анучин (1982) нарын өргөн хэрэглэгдэж буй арга зүйн дагуу явуулав $[8,9,10,11]$.

Шинэсэн ойн сэргэн ургалтыг А. В. Побединский (1962)-н арга зүйн дагуу ойн залуу үе удмыг цухуйц ба өсвөр мод гэж хувааж үзэв [12]. Цухуйцад 1 настайг, өсвөр модонд 2 ба түүнээс дээш настай модыг оруулав. Арга зүйн дагуу ойн судалгааны дээж талбай дотор өсвөр моддын тооллогыг түүний нас болон өндрөөс хамааруулан 2х2 м хэмжээтэй нийт 10 ш тооллогын талбайд гүйцэтгэв. Өсвөр мод цөөн, талбайдаа жигд бус тархсан тохиолдолд өсвөр моддыг бүгдийг тоолов.

Өсвөр моддыг модны төрөл, гарал 
үүсэл, нас өндрийн бүлгээр 10 см хүртэл өндөртэй, 11-50 см, 51-150 см, 151-300 см ба 300 см-ээс дээш гэж ангилан, дээр дурдсан өндрийн ангиллын хэмжээнд эрүүл, хэвийн хөгжилттэй, гэмтсэн ба хатсан мод гэж ялган тоолов. Өсвөр модны нас-өндрийн бүлэг тус бүрээс 2 загвар мод авч, тэдгээрийн нас, өндөр, дундаж өсөлт, сүүлийн жилийн өсөлтийг тодорхойлов.

Өсвөр модны тоог 1 га талбайд шилжүүээх болон тохиолдлын коэффициентийг тооцохдоо нийтлэг хэрэглэдэг дараах томъёонуудыг ашиглав. Үүнд:

$$
M=\frac{T^{*} 10000}{S}
$$

M -1 га талбай дах өсвөр модны тоо

T - тооллогын талбай дах өсвөр модны тоо $\mathrm{S}$ - бүх тооллогын талбайн нийлбэр $\left(\mathrm{M}^{2}\right)$ Өсвөр модны тохиолдлын коэффициент:

$$
K=\frac{\Pi_{i}}{\Pi} ;
$$

$\Pi_{i}$ - өсвөр модтой тооллогын талбайн тоо

\section{СУДАЛГААНЫ ҮР ДУН}

\section{1. БАЙГАЛИЙН СЭРГЭН УРГАЛТ БУХИЙ ШИНЭСЭН ОЙ}

Ойн сэргэн ургалтын тухай ойлголт нь эцсийн дүнд, биогеоценозын буюу экосистемийн ойлголтоор, ойн экосистемийн ойн бүлгэмдлийн сэргэн ургалт гэж авч үзэж болохыг И. С. Мелехов (1976) тэмдэглэсэн байдаг [13].

Ойн тасралтгүй хөгжлийн цикл үйл явцад ойн байгалийн сэргэн ургалт чухал Үүрэгтэй бөгөөд энэ нь ой үүсэн бүрэлдэх үйл явцын эхлэл үе юм.

Монгол Алтайн нурууны судалгаанд хамрагдсан шинэсэн ойн 19.2\%-ийг цухуйц бүхий ой, 11.5\%-ийг сэргэн ургалт хангалттай ой тус тус эзэлж байгаа ба
I - тооллогын талбайн нийт тоо

Монгол Алтайн нурууны Хан Тайшир, Хасагт Хайрхан болон Хархираа, Түргэний уулсын шинэсэн ойд хээрийн хэмжилт судалгааг 2003, 2004 онуудад гүйцэтгэсэн ба 6 дээж талбай байгуулж, байгалийн сэргэн ургалтын дээж 12ш, 2007 онд Хан Тайшир, Хасагт Хайрхан болон тэдгээрийн салбар уулс, Монгол Алтайн нурууны Хар Азаргын нурууны ой болон хавтгайруулан мод бэлтгэсэн талбайд 0.040.12 га хэмжээтэй нийт 15ш, 2008, 2010 онд Монгол Алтайн нурууны Цамбагарав уул, Ховд голын дагуух ой болон Даян, Хотон нуур орчмын ойд 5ш дээж талбай байгуулж, шаардлагатай хэмжилт судалгааг явуулж, дээж цуглуулсан болно.

Нийт 26 ш дээж талбайд байгалийн сэргэн ургалтыг үнэлэх 260 ш жижиг талбайг байгуулж, сэргэн ургалтын 72 ш загвар модыг төлөөлүүлэн сонгон авч, нас, өндөр болон диаметрийн өсөлтийг тодорхойлов.

нийтдээ 30.7\%-ийг байгалийн сэргэн ургалт бүхий ой эзэлж байна.

Ойн бүлгэмдлийн шинж чанар, байгалийн сэргэн ургалтын явцыг авч үзэхэд цухуйц бүхий ойд $3,4,8,9$-р дээж талбай, тооны хувьд хангалттай сэргэн ургалт бүхий ойд 7, 23, 25-р дээж талбайнууд тус тус хамаарна.

Байгалийн сэргэн ургалт бүхий ойд өсвөр моддыг өндрийн бүлгээр тоолж, өндрийн бүлэг тус бүрээс байгалийн аясаар сэргэн ургасан өсвөр моддын өсөлт, насыг тодорхойлох загвар моддыг авав. Дээж талбай дах өсвөр моддыг өндрийн бүлгээр ангилан тоолсон тоо хэмжээг 1га талбайд шилжүүлэн хүснэгт-1-д үзүүлэв. 
Хүснэгт-1. Шинэсэн ой доторх байгалийн сэргэн ургалтын тоо хэмюэээ (u/га)

\begin{tabular}{|l|c|c|c|c|c|c|}
\hline \multirow{2}{*}{$\begin{array}{c}\text { Дээж талбайн } \\
\text { дугар }\end{array}$} & \multicolumn{5}{|c|}{ Өндрийн бүлгийн ангилал (см) } & \multirow{2}{*}{ Дүн } \\
\cline { 2 - 6 } дТ-4 & $0-10$ & $11-50$ & $51-150$ & $151-300$ & $300<$ & $57500 \pm 9600$ \\
\hline ДТ-6 & $57500 \pm 9600$ & - & - & - & - & $77540 \pm 12300$ \\
\hline ДТ-7 & $41200 \pm 8800$ & $12400 \pm 2232$ & $10000 \pm 1670$ & $4800 \pm 817$ & $1200 \pm 228$ & $69600 \pm 15860$ \\
\hline ДT- 23 & $19000 \pm 3610$ & $430 \pm 69$ & $380 \pm 58$ & $80 \pm 13$ & $800 \pm 120$ & $20690 \pm 8312$ \\
\hline ДТ- 25 & - & $40 \pm 5$ & $1680 \pm 453$ & $1600 \pm 346$ & $2840 \pm 682$ & $6160 \pm 1149$ \\
\hline
\end{tabular}

Хүснэгт-1-ээс үзэхэд Монгол Алтайн шинэсэн ойд байгалийн сэргэн ургалтын тоо, өндрийн хэмжээ харилцан адилгүй байна. Хасагт Хайрхан уулын Хустайн нурууны уулын дээд хэсгийн ойд дунджаар 69600ш/га (ДТ-7), Ховд голын дагуух (гүүрний ойролцоох уулын дээд хэсэг) шинэсэн ойд дунджаар 20690 ш/га (ДТ-23), Даян нуур орчмын шинэсэн ойд 6160 ш/га (ДТ-25) хэмжээтэй байна. Хасагт Хайрхан уул, Ховд голын дагуух шинэсэн ойд байгалийн сэргэн ургалт өндрийн бүлгийн 0-10см ангилалд их байгаа бол Даян нуур орчмын шинэсэн ойд 3м-ээс дээш өндөртэй өсвөр модод давамгайлж байна.

Монгол Алтайн нурууны шинэсэн ойд (дээж талбай 7) 0-10 см-ийн өндрийн ангилалд сэргэн ургалт хамгийн их (41200 ш/га) тоологдсон байхад өндрийн бусад ангилалд өсвөр модны тоо хэмжээ эрс буурч, 11-50 см-ийн өндрийн бүлэгт 12400 ш/га, 51-150 см-ийн өндрийн ангилалд 10000 ш/ га, 151-300 см-ийн өндрийн ангилалд 4800 ш/га, 300 см-ээс дээш өндрийн ангилалд 1200 ш/га өсвөр модод байна. Сэргэн ургалтын насны бүтцийг авч үзвэл 0-10смийн өндрийн ангилалд 2-4 настай сэргэн ургалт, 11см-ээс дээш өндрийн ангилалд 2639 настай өсвөр модод хамаарагдаж байна. Иймээс 11см-ээс дээш өндрийн ангилалд хамаарч байгаа өсвөр модод насны II (20-40 настай) ангид багтаж байна.

Монгол Алтайн нурууны Ховд голын дагуух ойн (дээж талбай 23) байгалийн сэргэн ургалт 0-10 см өндрийн бүлэгт 19000 ш, өндрийн бусад үелэлд 80-800 ш/ га өсвөр мод тоологдов. 0-10 см өндрийн бүлэгт тоологдсон өсвөр мод 2-7 настай байхад бусад ангилалд тоологдсон өсвөр модод 30-45 настай байна.

Даян нуур орчмын шинэсэн ойд сэргэн ургалтын өндрийн бүлгийн 0-10 смийн ангилалд өсвөр модод тоологдоогүй бөгөөд өндрийн бүлгийн ангилал өгсөх тутам өсвөр моддын тоо нэмэгдэж байна. Тус ойд өсвөр модод шигүү ургасан байх ба насны хувьд бусад газрын өсвөр моддоос эрс ялгаатай байв. Өсвөр модод 40-60(70) настай ба насны III ангид хамаарч байна. айна.

Монгол Алтайн нурууны баруун хэсгийн ойн тархалтын гол цөм нь болох Сиргал, Ховд гол (Цэнгэл сум), Даян, Хотон нуур орчмын уул, нуруунд тархан ургасан шинэсэн ой нь нилээд онцлогтой.

Хотон нуур орчмын (Сиргал) нутаг дэвсгэрт гол төлөв ижил биш насны ой модод янз бүрийн өтгөрөлтэйгээр холилдон ургах ба хавтгайруулан мод огтолж байсан газрууд нь харьцангуй сайн сэргэн ургасан байх тул ижил насны залуу ой модод талбайн хувьд харилцан адилгүй хэмжээтэйгээр тохиолдоно. Тус бүс нутгийн хавтгайруулан мод огтолсон газарт залуу, дунд насны ой модод, мөн огтлолтоос үлдсэн хөгширч буй ой модод хэсэг бүлгээр тархан ургана. 


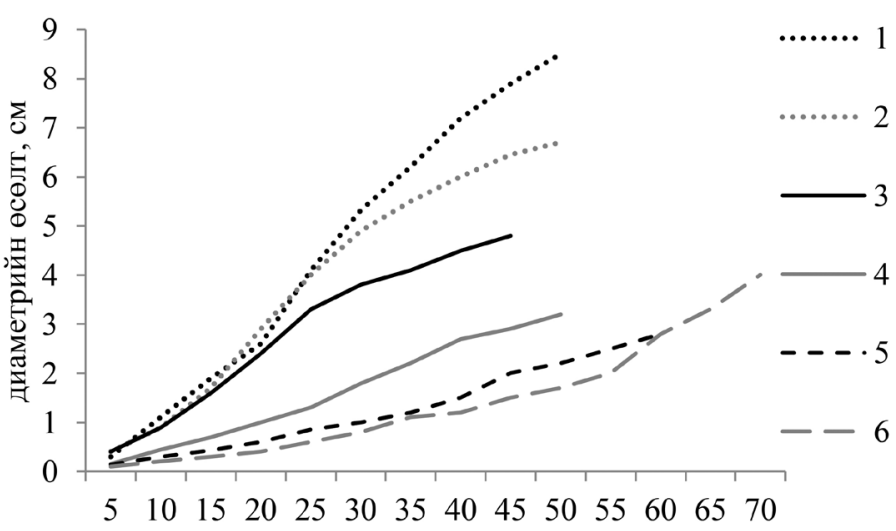

Нас, жил

Зураг 1. Өсвөр иинэс моддын диаметрийн өсөлтийн яви $\left(D_{0}\right)$

1, 2 - Мод огтолсон талбайд ургасан дунд насны (50-60) ой мод (дээж талбай 24); 3,4 - Ховд голын гүүрний ойролцоох шинэсэн ой доторх өсвөр модод (дээж талбай-23); 5,6- Даян нуурын ойролцоох иинэсэн ой доторх өсвөр модод (дээж талбай 25)

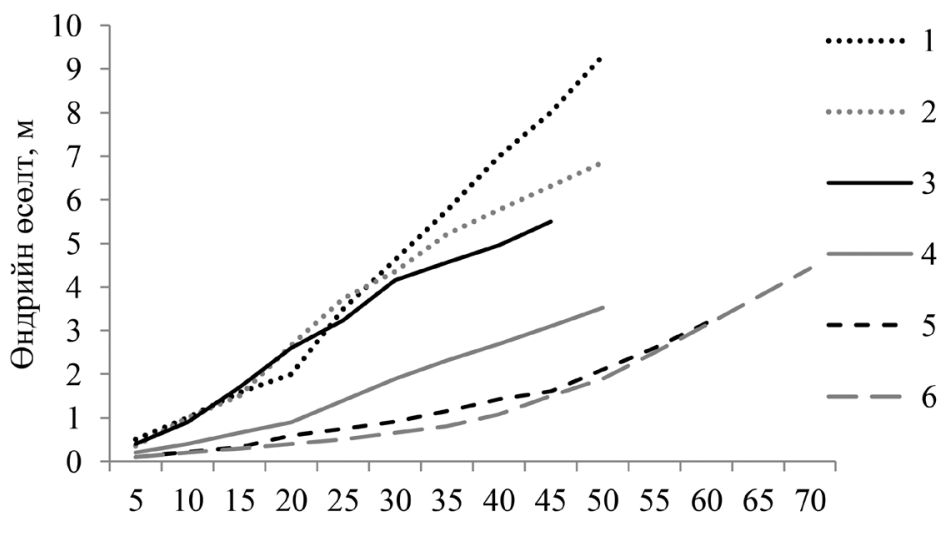

Нас, жил

Зураг 2. Өсвөр шинэс моддын өндрийн өсөлтийн яви

1, 2 - Мод огтолсон талбайд ургасан дунд насны (50-60) ой мод (дээж талбай 24); 3,4 - Ховд голын гүүрний ойролцоох шинэсэн ой доторх өсвөр модод (дээж талбай-23); 5,6-Даян нуурын ойролчоох шинэсэн ой доторх өсвөр модод (дээж талбай 25)

Зураг 1 болон 2-оос үзэхэд Сиргалийн дунд насны ой модод 50-60 настай, дундаж загвар мод 1 ба доминант загвар мод 2-ын диаметр 6.7 см ба 8.5 см, өндөр нь 6.85 м ба 9.3 м байхад Ховд голын гүүрний ойролцоох шинэсэн ой дотор ургасан өсвөр модод 4550 настай, дундаж загвар мод 3 ба доминант загвар мод 4-ын диаметр $3.2 \mathrm{~cm}$ ба $4.8 \mathrm{~cm}$, өндөр нь 3.53 м ба 5.5 м, Даян нуурын ойролцоох шинэсэн ой дотор ургасан өсвөр модод 60-70 настай, дундаж загвар мод 5 ба доминант загвар мод 6-ын диаметр $2.8 \mathrm{~cm}$ ба 4 см, өндөр нь 3.18 м ба 4.43 м байна. Эндээс үзэхэд Сиргалийн дунд насны ой моддын диаметр, өндрийн өсөлт бусад газруудынхаас харьцангуй сайн байна. Энэ нь ойн бүтэц, бүрэлдэхүүнээс ихээхэн хамаарч байна. 
Сиргалийн ижил насны залуу ой модод нь мод огтлолтын дараа үүсч, дан бүрэлдэхүүнтэйгээр энгийн ой үүсгэн ургасан байхад Ховд гол, Даян нуур орчмын шинэсэн ойд ургасан залуу модод тус ойн 3 дах үе удмыг үүсгэн ургаж байгаа учир өсөлт хөгжилт нь илүү хязгаарлагдмал байна.

Судалгаа явуулсан газар нутгийн ойд байгалийн сэргэн ургалт нь гол төлөв ойн чөлөө, цоорхой болон бага талбайгаар юмуу түүвэрлэж мод огтолсон ойд, хөвдөн бүрхэвч бүхий ойд ургасан байна.

Зүүн Хэнтийд өргөн тархсан хээржүу алаг өвст хэв шинжийн дан бүрэлдэхүүнтэй, дунджаар 45 настай, IIIIV бонитетийн шинэсэн ойд хийсэн өсөлт хөгжилтийн судалгаанаас Үзэхэд 5-10 насанд модны үндэсний систем харьцангуй бэхжиж, ойн бүлгэмдэл бэхжиж байна. Улмаар өсвөр мод өвслөг нөмрөгийг бүрэн давамгайлж, өөрийн бичил орчинг үүсгэсний дүнд температурын хэлбэлзэл багасч, агаарын чийгшилт ихэсдэг. Үүний дүнд моддын өндөр, эзлэхүүний өсөлтүүд эхний 5 жилийнхээс нилээд эрчимтэй явагдаж байна.

Өсвөр мод 10-20 настай болох үед гэрэлд дуртай өвслөг ургамлууд аажмаар үхэж, хөрсний бүрхүүлийн бүтцэд чанарын өөрчлөлт ордог. Энэ үед өсвөр модод хүрээлэн байгаa орчиндоо идэвхитэй нөлөөлж, гадны тохиромжгүй хүчин зүйлсийн үйлчлэлд нилээд тэсвэртэй болдог. Иймээс ч моддын өндөр диаметрийн өсөлт өмнөх жилүүдийнхээс огцом ихэсч байна. Мөн түүнчлэн нэгж талбай дах модны тоо дээд хэмжээндээ хүрдэг.

Ой мод 20-35 насандаа амьдралын шинэ шатанд орж, моддын өсөлт эрчимжиж,

\section{2. ШИнЭС МОднЫ ЦУХУЙЦ}

Хасагт Хайрхан уулын Шонт хэмээх газрын (дээж талбай 1) ширэгжээгүй хөрстэй ойн чөлөөнд 2003 оны 8-р сарын дунд үед 1 настай цухуйц дунджаар 310.0 титмийн нягтрал ихэсч, улмаар титмийн доод хэсгийн мөчир хүчтэй сүүдэрлэгдэн аажмаар унаж эхэлж байна.

Ой мод 35-45 наснаасаа үрээ өгч эхлэн моддын диаметр болон өндрийн өсөлтийн явц удааширч, ойн бүх бүрэлдэхүүн хэсгүүдийн өсөлт тогтонги байдалд орж байна. Ойн цаашдын амьдралд түүний бүрэлдэхүүн хэсэг болох сөөг, өсвөр мод, хөрс, амьтны аймаг бүрэлдэнэ. Иймд залуу моддын өсөлтийн явцыг дээшлүүлэхийн тулд 0.8-аaс дээш өтгөрөлтэй ургаж буй ойд арчилгааны огтлолтыг явуулах хэрэгтэй юм [14].

Байгалийн ховор ургамал болоод бүлгэмдлийн нөхөн сэргэлтийг дэмжихийн тулд тухайн нутаг дэвсгэрийг тодорхой хугацаагаар амраах, байгалийн өгөөж баялгийг амьдрал ахуйд ашиглах асуудлыг урт, богино хугацаагаар хориглож, услах бордох, арчлах зэрэг олон талт үйл ажиллагааг хэрэгжүүлэх нь нээлттэй нөхцөлд хамгаалах аргад хамаарна. Энэ бүх аргуудаaс экосистемийн хэмжээнд хамгаалах нь үр дүнд хүрэх хамгийн дөт бөгөөд хялбар арга юм [3].

Ойд болон ойн талбайд мал бэлчээхийг бүрэн зогсоох нь ойн бүлгэмдлийг хамгаaлах нэг чухал арга хэмжээ болно. Ийнхүу Монгол Алтайн нурууны хувьд ойд ургах байгалийн сэргэн ургалт нь гол төлөв бөөн бүлгээр ургах тул хэсэгчлэн хаалт, хашаа барих замаар өсвөр моддыг мал болон амьтдаас хамгаалах нь зүйтэй. ШигүҮ ургасан байгалийн сэргэн ургалтын нэгж талбайд ноогдох модны тоо хэмжээг тохируулах, тэжээлийн талбайг ихэсгэх, өсөлт ургалтыг нэмэгдүүлэх зорилгоор арчилгааны огтлолтыг явуулах шаардлагатай.

мян. ш/га, тохиолдлын коэффициент 30\%, харин системгүй мод огтолсон сийрэг ойн чөлөөнд дунджаар 130.0 мян. ш/га хэмжээтэй, тохиолдлын коэффициент 46\% 
байв. Харин 2004 оны 8-р сарын сүүлээр дээрх газруудад эргэн очиход ургаж байсан цухуйц байхгүй болсон байв.

Мод огтолсон талбайн (ойн чөлөө) бичил уур амьсгал нь нарны шууд тусгалаас хамааран эрс өөрчлөгддөг ба улмаар энэ нь цухуйц, өсвөр моддын амьдралтанд сөргөөр нөлөөлөх хүчин зүйл болдог байна [15]. Тухайлбал, Төв Хангайн шинэсэн ойн хавтгайруулан мод огтолсон талбайн хөрсний гадаргуугийн хамгийн их температур 6-р сард $59.4^{\circ} \mathrm{C}, 7-$ р сард $54^{0}$ $54.5^{\circ} \mathrm{C}$ хүрч байв [16].

ОХУ-д хийгдсэн туршилт судалгаанаас үзэхэд хавтгайруулан мод огтолсон талбайд хөрсний гадаргуугийн үнэмлэхүй хамгийн их температур $52^{\circ} \mathrm{C}$ хэмжээтэйгээр 5 минут үргэлжлэхэд цухуйц бүрэн үхдэг ба жижиг өсвөр моддын ургал эрхтэн шилмүүс, нахиа, найлзуур хүртэл хатаж, амьдрах чадваргүй болдог байна [17].

Төв Хангайн шинэсэн ойн хавтгайруулан мод огтолсон ихэнхи талбайд, хавтгайруулан бус огтолсон зарим талбайд ойн байгалийн сэргэн ургалтын үйл явц хангалтгүй байна $[18,19,20]$.

Хасагт хайрхан уулын (Сүмийн дэн) хөвдөн бүрхэвч бүхий шинэсэн ойн сийрэг хэсэгт (дээж талбай 4,) 3-4 настай сэргэн ургалт 57.5 мян. ш/га ургасан байгаа ба өндрийн бүлгийн 0-10 см хамаарна (хүснэгт 27). Сэргэн ургалтын тохиолдлын коэффициент $71 \%$ байна.
Хасагт Хайрхан уулын Хустайн нурууны ойн дээд хэсэгт хөвдөн бүрхэвч бүхий шинэсэн ойд (дээж талбай 6) микрорельеф ихтэй ба дэвсэгдүҮ хэсэгт 2-3 настай сэргэн ургалт ихээр ургажээ. Байгалийн сэргэн ургалтын тоо хэмжээг тооцоход 77.5 мян. ш/га байна (хүснэгт-1). Сэргэн ургалтын тохиолдлын коэффициент $64 \%$ байна. Эндээс үзэхэд ургах орчны тодорхой нөхцөл бүрдэж, байгалийн аясаар үрээс ургаж буй эхэн үеийн сэргэн ургалт маш их тоо хэмжээтэй байна.

Төв Хангайн тайгажуу шинэсэн ойн түүвэрлэн мод огтолсон ойд хийсэн судалгаанаас үзэхэд өсвөр шинэс 1 га талбайд 11.5 мян.ш тоологджээ. Мод огтлолтоос үлдсэн хэсэг бүлэг модны дунд, талбайд үлдсэн том модны үдийн сүүдэр тусдаг газар, ойн хананы ойролцоо, тэрчлэн хөвдөн бүрхүүл бүтэн үлдсэн газарт өсвөр мод гэмтэлгүй хадгалагдан үлджээ. ЧухамхүҮ эдгээр газарт л цухуйц гарч ирэх ба улмаар хадгалагдан үлдэж байна [4].

ИйнхүY 1 настай цухуйц ургасан ойд цухуйцын мэнд үлдэлтийг хамгаалан газрын гадаргын орчмын хэт халалтаас сэргийлж, сүүдэрлэх арга хэмжээг авах нь зүйтэй. Үүний тулд ойд унасан моддыг авч ашиглахгүйгээр ойд нь үлдээх, мөн түүнчлэн хатсан унасан мод, мөчрийг ашиглан зохиомол сүүдрэвчийг бий болгож цухуйцыг нарны цонолтоос хамгаалах нь цухуйцын мэнд үлдэлтийг нэмэгдүүлэх юм.

\section{3. БАЙГАЛИЙН СЭРГЭН УРГАЛТГУЙ ШИНЭСЭН ОЙ}

Ой байгалийн аясаар сэргэн ургаж үүсэн хэлбэржих, өсөж ургах үйл явцад олон хүчин зүйлс нөлөөлж байдаг. Монгол Алтайн бүс нутгийн ойд говь, цөлийн уур амьсгалын нөлөөллөөс гадна хүний хүчин зүйлс ихээхэн нөлөө үзүүлж байна. Ой модны өнөөгийн төрх байдал нь тэдгээрт урт хугацааны туршид хүний хүчин зүйлс нөлөөлж байсныг илтгэнэ [21].

Монгол Алтайн нурууны ойн захаар ойгоо тэлэх замаар ургах байгалийн сэргэн ургалт төдийлөн байхгүй. Хар Азаргын нурууны Их Өргөн мод, Даян ба Хотон нуур орчмын ойн дээд захад хэсэг хэсгээр, бөөнөөр ургасан өсвөр моддын оройн нахиа болон сүүлийн жилүүдийн өсөлтийг бүгдийг идэж, гэмтээсэн байдал их тохиолдоно [22].

Ойн байгалийн сэргэн ургах үйл явц хязгаарлагдсан ой нь судалгааны ойн 
талбайн 69.3\%-ийг эзлэх ба байгалийн 24, 26-р дээж талбайнууд хамаарч байна. сэргэн ургалтгүй байгаа ойд $1,2,5,10-21$,
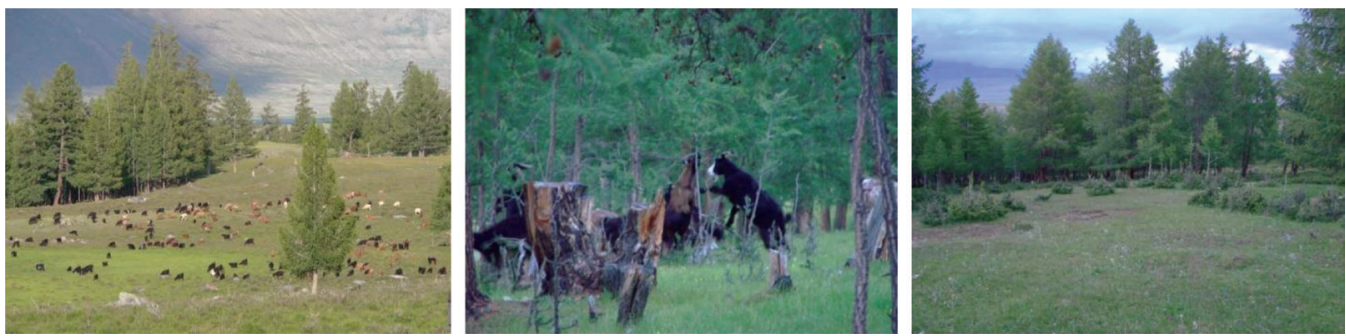

Зураг 3. Ойн талбай дах мал сүргийн бэлчээрлэлт ба идэгдсэн өсвөр модод

Судалгаа явуулсан тус бүс нутгийн хэмжээнд ойн дээд, доод зах, ойн цоорхой, мод бэлтгэсэн талбайд мал сүрэг ихээр бэлчээрлэдэг нь бий болсон малын жим болон орой нь идэгдсэн өсвөр моддоос (зураг-3), мөн ойн ургамлын өөрчлөгдлийн судалгаанаас тодорхой харагдана. 9-р дээж талбайн байрлах ойн дээд захад бөөн бүлгээр ургасан сэргэн ургалтын тоо 1га талбайд 1250 ш/га байгаа ба 100\% идэгдэж гэмтсэн байна. Идэгдсэн өсвөр моддын дундаж нас 36, дундаж өндөр 68 см байна. Идэгдэж гэмтсэн өсвөр моддын гадаад хэлбэр нь бут сөөг мэт харагдана.

Байгалийн сэргэн ургалт байхгүй байгаа ойд дараа дараагийн залгамж үе удам үүсэж бий болох нөхцөл бүрдэхгүй байгаагийн илэрхийлэл юм.

Ойд мал бэлчээх нь түүний эрчмээс хамаарч, ойн сэргэн ургах үйл явцад ялгаатай нөлөө үзүүлдэг ба харин өмнөх жилийн хагдарсан өвс нь модлог ургамалд сөрөг нөлөө үзүүлэхгүй, харин байгалийн сэргэн ургалтын үйл явцад саад учруулдаг

\section{4. ОЙГ ХАМГААЛАХ ЗАГВАР}

Монгол Алтайн нурууны шинэсэн ойг нийтэд нь нэг аж ахуйн нэгж болгон авч үзэх явдал өсөлт хөгжилт удаан, ургах орчин нөхцөл муутай, бүтээмж бага, гадны сөрөг нөлөөнд өртөмтгий тухайн бүс нутагт зохимжгүй ба харин төгөл тархалттай тус ойг бүлгэмдлийн шинж чанараар нарийвчлан зохион байгуулах байна. Түүнчлэн ойн газрыг малын бэлчээрт эрчимтэй ашигласнаар сөөг ургамал болон өсвөр мод устахад хүргэдэг $[23,24]$.

Монгол Алтайн тайгажуу өндөрлөг бүслүүрийн шинэсэн ой дотор байгалийн нөхөн ургалтын үйл явц байнга хангалттай бус, харин түүвэрлэх огтлолтоор талаас дээш хувийг огтолсон, өтгөрөл нь 0.3 хүртэл сийрэгжсэн ой дотор нөхөн ургалтын үйл явц хангалттай явж байна (сор.тал.123). Уулын хээр, царамтай хил залгаа, малын бэлчээрт ашиглагддаг мод огтолсон талбай туйлын муу нөхөн ургаж байна. Аж ахуйн сөрөг үйл ажиллагаа нь ойн сэргэн ургалтын явцыг зогсоож, ойн талбай хорогдох, усны горимыг зохицуулах, хөрс хамгаалах ҮҮргийг алдагдуулж байна [4].

Хүний хүчин зүйлийн нөлөөллийн улмаас экологид гарах үндсэн өөрчлөлтийг тогтоосноор экологийн үр нөлөөний талаарх ойлголтыг гүнзгийрүүлэх, мөн экологийн мониторинг ба менежментийг боловсронгуй болгох чухал хэрэгсэл болох юм $[25,26]$.

ойн менежментийн аргыг хэрэглэх нь зохистой арга хэмжээг авч хэрэгжүүлэх, ойг хамгаалахад үр дүнтэй юм.

Иймээс бид Монгол Алтайн нурууны ойг хадгалан хамгаалах загварчлалыг боловсруулав (зураг-4). Ойг хамгаалах загварчлал нь [а], [б], [в] гэсэн үндсэн 3 хэсгээс бүрдэнэ. 
[а] - хэсэгт Монгол Алтайн нурууны ойг хамгаалах зорилгыг тодорхойлох, байгалийн сэргэн ургалтын явц болон уг бүтээлийн IV бүлгийн хүснэгт-15-д үзүүлсэн ойн бүрэлдэхүүн, насны бүтэц, ургах орчин нөхцлийг үнэлсэн үзүүлэлт дээр үндэслэн ойн бүлгэмдлийн шинж чанарыг тодорхойлох талаар тусгав.

Монгол Алтайн нурууны ойг хамгаалах үндсэн зорилго нь экосистемийн үүрэг, ач холбогдлыг алдагдуулахгүйгээр хэвээр нь хадгалан хамгаалахад оршино.

[б] - Ойг A1, A2, A3, A4, B1, B2, В3 гэсэн аж ахуйн нэгжид ангилна.

A ойн A1 аж ахуйд нөөцийн хувьд ойн бүрэлдэхүүн нь Шс $(>100) Ш \mathrm{c}(<40)$ байх, насны 2 үе удмаас бүрдэх ойг, А2 аж ахуйд ойн бүрэлдэхүүн нь Шс(>100)Шс(41$100) Ш c(<40)$ байх, насны 3 үе удмаас бүрдэх ойг, А3 аж ахуйд ойн бүрэлдэхүүн нь Шс $(>100) Ш c(>100) Ш c(<40)$ байх, насны 3 үе удмаас бүрдэх ойг, A4 аж ахуйд ойн бүрэлдэхүүн нь Шс(>100)Шс(>100)Шс(41$100)+Ш c(<40)$ байх, насны 3 үе удмаас бүрдэх, ургах орчин нөхцлийг үнэлэх бонитетийн IV, V ангид хамаарах ойг тус тус хамруулна.

В ойн В1 аж ахуйд нөөцийн хувьд ойн бүрэлдэхүүн нь 10Шс $>100)+Ш c(41-100)$ байх, насны 1-2 үе удмаас бүрдэх ойг, В2 аж ахуйд ойн бүрэлдэхүүн нь Шс $(>100)$ Шc $>100)$ байх, насны 2 үе удмаас бүрдэх, В3 аж ахуйд ойн бүрэлдэхүүн нь Шс(41$100) Ш c(>100)$ байх, насны 2 үе удмаас бүрдэх, ургах орчин нөхцлийг үнэлэх бонитетийн $\mathrm{V}, \mathrm{V}_{\mathrm{a}}, \mathrm{V}_{\text {б }}$ ангид хамаарах ойг тус тус хамруулна.

Ойд авч хэрэгжүүлэх ой хамгааллын ижил арга хэмжээгээр нь аж ахуйнуудыг бүлэглэн А ба В гэсэн ойд бүлэглэнэ. Үүнд:

1) $\mathrm{A}$ ой- Байгалийн сэргэн ургалт бүхий ой

2) В ой- Байгалийн сэргэн ургалтгүй ой болно.

[в] - хэсэгт А ба В ойг хамгаалах арга замыг тусгав. “А” ой буюу байгалийн сэргэн ургалт бүхий ойн экосистемийн үүрэг, ач холбогдлыг алдагдуулахгүйгээр хэвээр хадгалан хамгаалахад чиглэгдэнэ. Тус ойг хамгаaлах арга замын хүрээнд цухуйц болон өсвөр модыг хамгаалах асуудлыг онцлон авч үзэх болно.

“В” ой буюу ойн байгалийн сэргэн ургалт нь гадны хүчин зүйлсийн үйлчлэлээр хязгаарлагддаг дунд насны болон хөгширсөн ойд байгалийн сэргэн ургалтыг дэмжих, хөгширсөн ойн дараачийн үе удмыг бий болгох зорилгоор ой дотор тарьц, суулгацыг зориудаар тарьж ургуулах зэрэг арга хэмжээг авч, хамгаалахад чиглэгдэнэ.

Монгол Алтайн бүс нутаг ой модны нөөцөөр бага, ой нь хэсэг хэсэг, төгөл тархалттай хэдий ч тухайн бүс нутгийн экосистемд Үзүүлэх нөлөө нь их учир юуны өмнө ойг хамгаалж хадгалан үлдэх нь юунаас ч чухал бөгөөд байгалийн сэргэн ургалт нь хязгаарлагддаг ой болон байгалийн аясаар сэргэн ургах чадваргүй хөгширсөн ой дотор тарьц, суулгац ашиглан зориудаар тарьж ургуулах нь урт удаан хугацаанд ойтой байх, ойн талбайг бууруулахгүй байх үндсэн нөхцөл болно. 


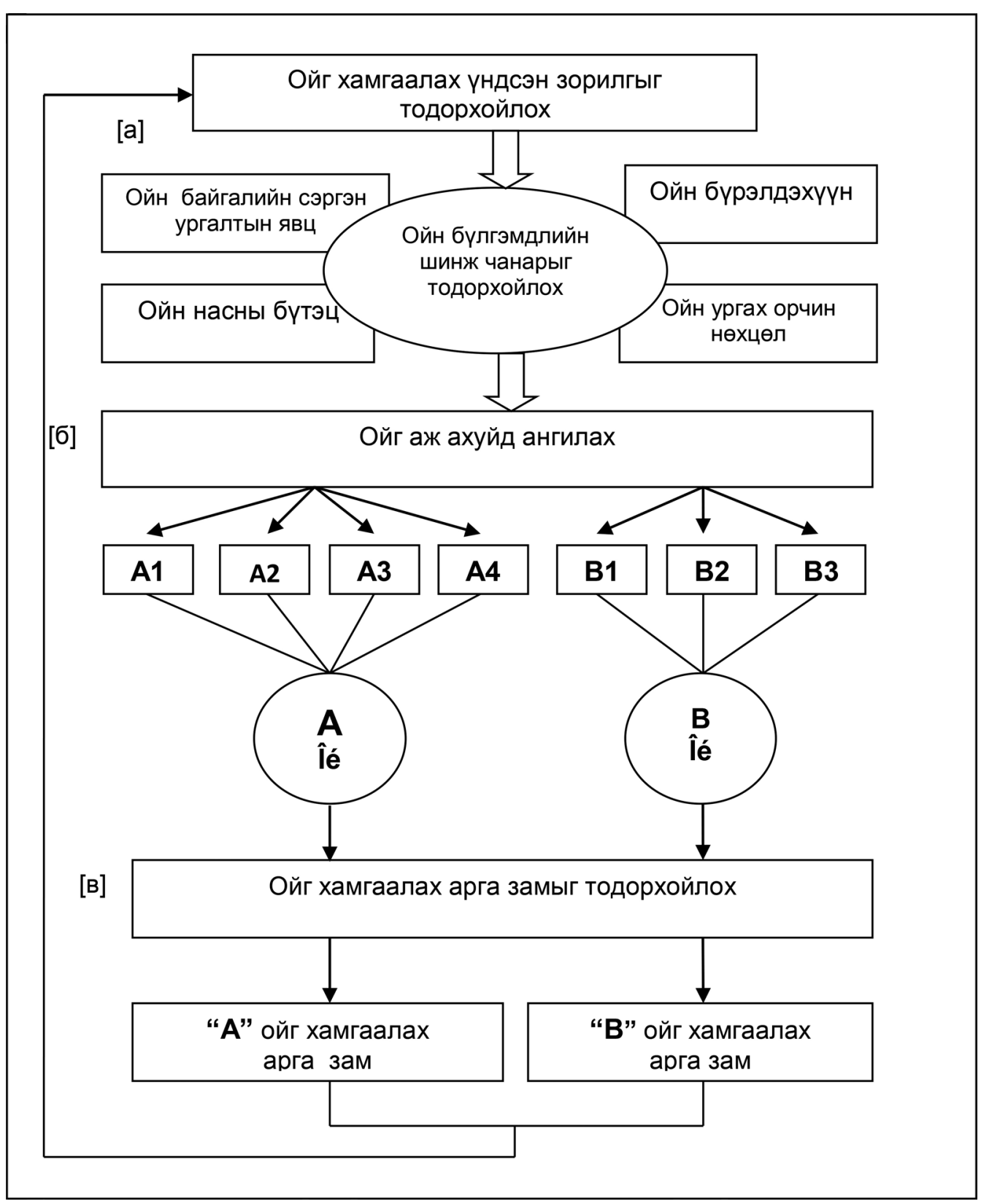

Зураг 4. Монгол Алтайн нурууны ойг хамгаалах загвар 


\section{ДҮГНЭЛТ}

1. Ойн өсөлт, түүний эрчим болон бүтээмж бага, их газар нутагт бага талбайгаар “төгөл” тархалттай ургах Монгол Алтайн нурууны ойг нэг бүхэл аж ахуй болгон авч үзэх бус, ойг хамгаалах загварчлалын дагуу төсөөтэй шинжээр нь аж ахуйн нэгжид бүлэглэн, түүнд тохирсон ялгаатай арга хэмжээг авч хэрэгжүүлэх нь тус бүс нутгийн ойн хөрс хамгаалах, ус зохицуулах экосистемийн үүрэг, ач холбогдлыг хэвээр хадгалах, биологийн бүлгэмдлийг хамгаалах практик арга хэмжээ болно.

2. Байгалийн аясаар сэргэн ургах үйл явцад нөлөөлж буй нэг хүчин зүйл болсон ойд болон ойн орчинд мал бэлчээх явдлыг зогсоож, цухуйц болон өсвөр моддыг хамгаалах нь зүйтэй.

3. Байгалийн сэргэн ургалт бүхий ойд өсвөр модод хэт шигүҮ ургасан нь диаметрийн өсөлтийг хязгаарлаж байна. Иймд шигүҮ ургасан өсвөр моддын тоо хэмжээг тохируулах, өсөлтийг нэмэгдүүлэх зорилгоор арчилгааны огтлолтыг явуулах нь зүйтэй.

4. Говь, цөлийн нөлөө ихтэй тус бүс нутагт ойн залгамж халаа болох өсвөр модод ургах нөхцлийг бүрдүүлэх, ойн талбайг бууруулахгүйгээр ойгоо хадгалан хамгаалах, залгамж халааг бий болгох зорилгоор сэргэн ургалт нь хязгаарлагдсан хөгширсөн ойд тарьц, суулгацыг зориудаар тарьж ургуулах шаардлагатай.

\section{Ашигласан бүтээлийн жагсаалт}

1. Коротков. И. А., Цэдэндаш Г. (1983). Карта лесов МНР. М 1:1.5 млн. ГУГК СССР и ГУГК MHP. M.

2. Ричард Б. Примак., Д. Батболд., Р. Самъяа., Н. Батсайхан. 2003. Байгаль хамгааллын биологи. Улаанбаатар, х. 422.

3. Самъяа .Р., Мюленберг .М. (2006). Монгол орны байгаль хамгаалал. Хэвлэлийн газар “Мөнхийн Үсэг”ХХК, Улаанбаатар, 325 х.

4. Дугаржав. Ч. (2006). Монгол орны шинэсэн ой. Бемби сан хэвлэлийн газар, Улаанбаатар, $318 x$.

5. Леса Монгольской Народной Республики. (География и типология). Наука, М., 1978. 127 c.

6. Энхсайхан.Д. 2002. Алтай-Соёны экобүс нутгийн биологийн төрөл зүйлийг хамгаалах, тогтвортой ашиглах төслийн хүрээнд тус бүс нутагт ажилласан шинжээчдийн тайлан, Улаанбаатар.

7. Бекет. У. (2003). Монгол Алтайн нурууны ургамалжсит, түүнийг ашиглах, хамгаалах асуудлууд, ШУ-ны докторын зэрэг горилсон бүтээл. дисс, Улаанбаатар, 269 х.

8. Моисеев. В. С. (1971). Таксаиия молодняков. Изд. ЛТА, Л., 343 с. Морозов. Г. Ф. (1931). Учение о лесе. М.-Л.: Сельхозгиз, 438 с.

9. Мошкалев А. Г., Моисеев В. С., и др. (1988). Закладка лесотаксачионных и дешифровочных пробных площчадей. Л., $78 \mathrm{c.}$

10. Моисеев. В. С., Нахабцев. И. А., Яновский. Л. Н., и Мошкалев. А. Г. (1987). Лесная таксация. учебное пособие, Л., $80 \mathrm{c}$.

11. Анучин. Н. П. (1982). Лесная таксаиия. Изд. Лесная промышленность, М., 520 c.

12. Побединский.А. В. (1962). Изучение лесовосстановительных прочессов. (методические указания) Красноярск. 63 с.

13. Мелехов .И .С. (1976). Биология, экология и география возобновления леса.-В кн.:Возобновление леса. М.: Колос, с. 4-21.

14. Цогт. 3. (1997). Залуу шинэс модны өсөлтийн онилог. БОЯ, Ойн ан судлалын хүрээлэн, 
Эрдэм иинжсилгээний бүтээл '3, УБ, х. 42-47.

15. Красношеков. Ю. Н., Коротков И. А., Доржсурэн Ч. (1981). О микроклимате под пологом леса и на вырубках в псевдотаежных лиственничниках в связи с возобновительными проиессами.-Тр. Инс-та ботаники, Уланбатор, №5, с. 36-46.

16. Дашзэвэг. Ц. (1990). Культуры лиственниць сибирской в лиственничных лесах Центрального Хангая и Восточного Хэнтэя МНР. дисс.канд.с/наук, Красноярск, 146 с.

17. Гирс. Г.И., Зубарева. О. Н. (1979). Устойчивость вегетативных органов хвойных к высокой температуре.-В кн.: Реакция хвойных на действие повреждаюших факторов. Красноярск, с.5-14.

18. Дугаржав. Ч., Коротков.И.А., Савин.Е.Н. (1975). Леса хребта Тарбагатай в Монголии// Леоведение, №2 с. 38-46.

19. Савин. Е. Н., Дугаржав Ч. (1980). Возобновительные проиессы в лесах МНР// Леса МНР “Хозяйственное использование”. М., с. 6-65.

20. Дугаржав. Ч. (1980). Естественное возобновление лиственниць сибирской в лесах Хангая, МНР. //Автореф. дисс. канд. с/х наук. Красноярск, 26 с.

21. Краснощеков. Ю. Н., Евдокименко. М. Д. (1990). Влияние пожаров на противоэрозионную устойчивость почв лиственничных лесов Восточного Хэнтэя.// Методологические вопросы оценки состояния природной среды МНР. Пущчино, с. 76-77.

22. Цогтбаатар. Ж., Баттулга. П. (2008). Говь-Алтай, Монгол Алтайн нурууны иинэсэн ойн байгалийн сэргэн ургалт. ШУТИС-ийн эрдэм иинжилгээний бvтээл. №1/96, ШУТИС, Улаанбаатар, х. 95-103.

23. Морозов. Г. Ф. (1931). Учение о лесе. М.-Л.: Сельхозгиз, 438 с.

24. Лащуинский. Н. Н. (1961). Естественные возобновление лиственницы сибирской в главных типах леса Горного Алтая. Автореферат.канд.дис. Новосибирск, 18 с.

25. Elliott, K. J., Hedrick, R. L., Major, A. E., Vose, J. M. and Swank, W. T. 1999. Vegetation dynamics after prescribed fire in the southern Appalachians. Forest Ecology and Management 114: 199-213.

26. Dale, V. H., Beyeler.S C and Jackson . B. 2002. Understory vegetation indicators of anthropogenic disturbance in longleaf pine forests at Fort Benning, Georgia, USA. Ecological Indictors 1(3): 155-170. 